
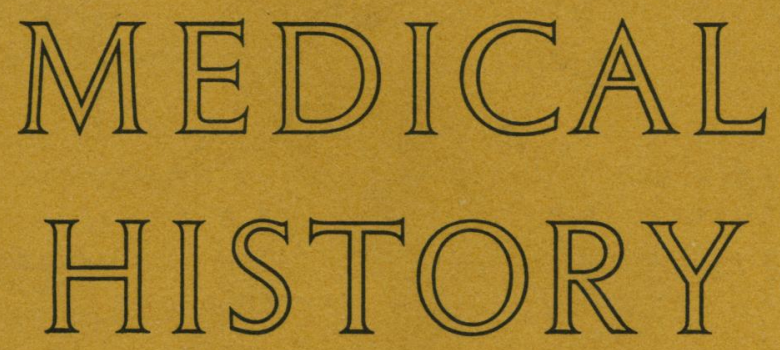

A QUARTERLY JOURNAL

DEVOTED TO THE HISTORY AND BIBLIOGRAPHY OF MEDICINE AND THE RELATED SCIENCES

Volume I Number 3

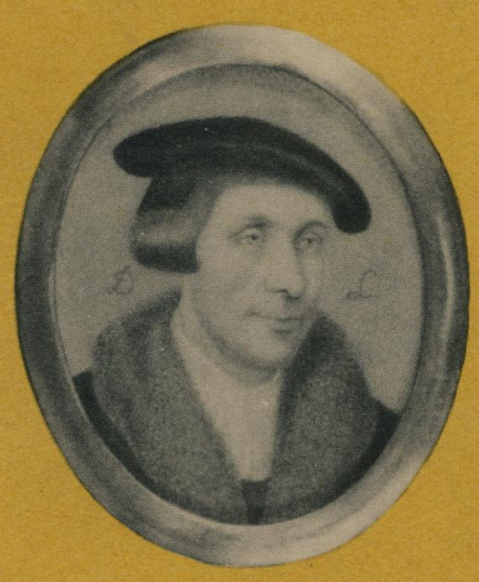

JULY I 957

WM DAWSON \& SONS LTD

${ }_{4}$ Duke Street, Manchester Square, London WI 


\section{CONTENTS}

Volume I

JULY 1957

Number 3

Main Articles

OSGAR WILDE: A MEDICAL APPREGIATION

MACDONALD GRITGHLEY

Page 199

THE HISTORY OF THE FLANNEL BINDER

AND GHOLERA BELT

E. T. RENBOURN

Page 2 II

GHRISTIAN RICKMANN (I74I-72): A FORGOTTEN

PIONEER OF SOGIAL MEDIGINE

GYRIL G. BARNARD

Page 226

REGURRENT THEMES IN THE HISTORY OF PSYGHIATRY DENIS LEIGH

Page 237

AVIGENNA-HIS LIFE AND TIMES
REUBEN LEVY
Page 249

THE GOUT OF WILLIAM GEGIL-FIRST LORD BURGHLEY

( 1 520-98)

W. s. C. COPEMAN

Page 262

Harvey Tercentenary

WILLIAM HARVEY: THE MAN AND THE GOLLEGE

OF PHYSIGIANS

K. D. KEELE

Page 265

Texts and Documents

Certificate of Attendance at William Smellie's Lectures, 1757. P. H. Nankivell.

Society Reports

Cambridge University History of Medicine Society; Norwegian Society for the History of Medicine; Osler Club of London; Royal Society of Medicine (Section of the History of Medicine); Scottish Society of the History of Medicine.

\section{Obituary}

Henry E. Sigerist (1891-1957). Walter Pagel.

News, Notes and Queries

History of the Term 'Neurosis; Pagine di Storia della Medicina; Polish Institute of Medical History.

Book Review

La Médecine Hippocratique. Charles Lichtenthaeler. 


\title{
Medical History
}

\author{
A QUARTERLY JOURNAL \\ DEVOTED TO THE HISTORY AND BIBLIOGRAPHY OF \\ MEDIGINE AND THE RELATED SGIENGES \\ OFFICIAL ORGAN OF \\ THE GAMBRIDGE UNIVERSITY HISTORY OF MEDIGINE SOGIETY \\ THE NORWEGIAN SOGIETY FOR THE HISTORY OF MEDIGINE \\ THE SCOTTISH SOCIETY OF THE HISTORY OF MEDICINE \\ THE OSLER GLUB OF LONDON
}

Editor: W. J. Bishop

\section{NOTIGE TO GONTRIBUTORS}

Contributions, which may deal with any aspect of medical history or bibliography, are invited. The maximum length for original articles is about 10,000 words. Previously unpublished texts and documents, short papers, and bibliographical notes and queries will also be welcomed.

Manuscripts should be typewritten with double spacing and wide margins. The Editor reserves the right to make literary corrections. Captions or legends of illustrations should include particulars of their source and should be typed on a separate sheet. No particular style of bibliographical citation is insisted upon, but contributors are asked to pay special attention to the accuracy of their references.

A galley proof, which should be corrected and returned to the Editor as quickly as possible, will be sent to every contributor of an original article.

Contributors will receive fifty reprints free of cost. Particulars of the cost of additional reprints will be sent with galley proofs.

Manuscripts, review copies of books and reprints, and correspondence relating to the publication of papers should be addressed to the Editor, Medical History, c/o William Dawson \& Sons Ltd., 4 Duke Street, Manchester Square, London, W.I.

\section{SUBSGRIPTIONS}

Medical History is published quarterly on the ist January, April, July and October.

The subscription rate is $£ 2$ Ios. od. a year in the United Kingdom, and $\$ 7.50$ in Canada and the U.S.A. Single issues can be purchased at I5s. each.

All subscriptions and orders, and inquiries regarding advertising, should be addressed to William Dawson \& Sons Ltd., 4 Duke Street, Manchester Square, London, W.I. 


\section{OUR GOVER DESIGN}

The miniature portrait of Thomas Linacre which appears on our cover is reproduced from a portrait inset into the binding of a copy of the 1492 edition of Seneca in the Wellcome Historical Medical Library. 